\title{
Paideusis
}

\section{"Philosophical Scaffolding for the Construction of Critical Democratic Education" (Richard A. Brosio)}

\section{Harold Entwistle}

Volume 14, Number 2, 2001

URI: https://id.erudit.org/iderudit/1072798ar

DOI: https://doi.org/10.7202/1072798ar

See table of contents

Publisher(s)

Canadian Philosophy of Education Society

ISSN

0838-4517 (print)

1916-0348 (digital)

Explore this journal

Cite this review

Entwistle, H. (2001). Review of ["Philosophical Scaffolding for the Construction of Critical Democratic Education" (Richard A. Brosio)]. Paideusis, 14(2), 59-62. https://doi.org/10.7202/1072798ar 


\section{Philosophical Scaffolding for the Construction of Critical Democratic Education by Richard A. Brosio ${ }^{1}$}

\section{Reviewed by Harold Entwistle, Concordia University of Montreal}

Richard Brosio identifies himself as a teacher-scholar and this text is a testament to the quality of his work in both of these roles. His skills as a teacher are manifest in the lucidly written text which intermittently has the style of a conversation between author and reader. Throughout the text there are sections headed "Suggested Tasks for the Reader". These tasks invite genuine interaction, requiring a much more informed and critical response from the reader than the more familiar end-of-chapter exercises intended to test the reader's grasp of the material. Brosio's tasks are invitations to the reader to think through with him the implications of his argument and of the philosophical positions he discusses for theory of education and for the reader's own theorising and practice. A good example of this is the way in which students are invited to analyze their experiences and those of their peers in light of the Gramscian concept of hegemony.

Brosio seeks his philosophical scaffolding in the works of historical figures within the Western philosophical and religious traditions and from the various philosophical isms - idealism, essentialism, perennialism, realism, marxism, progressivism, existentialism. This alternative style of educational philosophising was marginalised during the period of several decades when analytical philosophy dominated the field of philosophy of education, being often dismissed as mere history of educational thought with little relevance for the contemporary understanding of educational theory and practice. But Brosio's is not a mere chronological survey of classical texts and seminal positions from the history of philosophy. Contributors to the great philosophical tradition are relevant to him for the way in which they illuminate his project - the construction of a framework for critical democratic education.

The conception of democracy advanced by Brosio is not one which is widely held in the establishment political ideology of most so-called Western democracies. He cites Dewey's belief that the United States was not then a democracy, a judgement echoed by Brosio himself with reference to the present day. This is ironic in view of the self proclaimed mission of the United States to bring democracy to the rest of the world and, especially, to newly created nation states. However, Dewey's and Brosio's conclusion has recently drawn support from ex-President Carter's opinion that if his organisation which responds to invitations 
from incipient democracies to monitor their electoral procedures had been invited to monitor the recent Presidential elections in Florida, these would not have met his organisation's criteria for free and fair elections.

In dismissing the United States as not democratic (and, by implication, other Western democracies like Canada), Brosio is committed to what has variously been categorised as 'strong', 'associational' or 'participatory' democracy, in contrast to 'weak', or what Schumpeter called 'elite' democracy. The latter is essentially the representative, parliamentary conception of democracy, where party elites compete for the votes of citizens in occasional general elections, citizen participation in government being confined to this occasional role as voter. The former, strong participatory democracy, is essentially a function of the manifold institutions of civil society where citizens associate in order to understand and further their interests in relation to the various economic, vocational, political, social, environmental and cultural dimensions of their lives. No doubt these interests are often self-centred, but they are also frequently altruistic or disinterested, as when an association's objectives are charitable, or on behalf of minorities or, more generally, in pursuit of the public good. It is this distinction between the differing weak and strong conceptions of democracy which is essential when the demonstrations prompted by international conferences from Seattle to Quebec City are dismissed as undemocratic by critics, or as genuine manifestations of democratic activity by the demonstrators and their sympathizers. Unfortunately, the 'democratic', anticapitalist demonstrations now seen throughout the economically advanced postindustrial world are vitiated, not only by minority violence but also (perhaps necessarily - you cannot have interactive dialogue on banners and through repetitive chants) by the parade of slogans and cliches necessary to engender enthusiasm but of little value in promoting productive dialogue. By reference to Habermas and his notion of a 'communicative ethic', Brosio reminds us that democratic discourse requires critical questioning and answering of each other in non-coercive conditions through which mutual understanding and intersubjective agreement can be reached. Hence, a primary task of a critical democratic education lies in the creation of constant opportunities for open, informed and critical dialogue in schools.

To underline his plea for commitment to the alternative of critical democracy, Brosio also stresses the importance of knowing and understanding the implications of those philosophies which support his position, as well as of historically influential philosophical positions which appear less friendly to the authentic democratic project he espouses.

The inspiration for critical democratic education in Brosio's sense lies in the 
writings of those philosophers and philosophical -isms which he discusses in the chapters on what he calls 'Various Reds' (Marx himself, Gramsci, the Frankfurt school), Dewey (who, lacking an adequate critique of capitalism's role in undermining democracy, nevertheless provides the correlative pedagogical ingredient which Marxism lacks) and Existentialism. In this last, Brosio also discusses the reasons for the less than successful attempts by American pragmatists to assimilate existentialism, but also the similar concerns which led to these attempts. With reference to marxism, we are reminded that this is central to the Western intellectual tradition, an influence unaffected by the demise of Soviet Communism or the alleged death of socialism. In this context, Brosio observes that Marx would have been a rebel in twentieth century states masquerading as marxist and that there is a tradition of democratic marxism of relevance to anyone interested in making both school and society more democratic, just and "responsive to the wonderful variety of the human family."

It is unsurprising that Brosio should seek his scaffolding for a critical democratic education in the writings of "various reds" and other sympathetic progressive philosophies. It is less obvious why he would also pay sympathetic attention to a discussion of more than two millennia of philosophers and theologians whose work he and other critics have categorised as unfriendly to democracy, even authoritarian in their implications and, frankly, undemocratic. This earlier historical tradition dating back to Ancient Greece is seen as a quest for epistemological and ethical certainty; a quest which has also dominated the ideology and practice of American schools with their philosophical scaffolding of educational essentialism, philosophical idealism and/or realism and socio-political conservatism. However, although he believes this quest to be a thoroughly misconceived enterprise, ultimately unfriendly to his own democratic project, his dismissal of the quest is not pejorative. The quest for certainty has been and remains understandable, even if fruitless. But the examples of the philosophical and religious endeavours in the quest for certainty which are cited here are offered, in part, as potentially illuminating and educational for those who are committed to the democratic project. As Brosio suggests (a reminder of Gramsci's insistence that the adversary is 'the entire thought of the past'; hence an essential ingredient of everyone's schooling), knowing how our ancestors went about the task of making sense of their worlds is an essential inspiration to our own search for wisdom and understanding of our own life and work. Moreover, although ultimately frustrated in reaching certainties which respect the human person and his/her democratic rights and aspirations, these religious and metaphysical traditions, from the Ancient Greeks on down, have 
inevitably bequeathed values and institutions which are themselves essential to the democratic project. From the Greeks we inherit the conception of pro publico bono, the notion that private individualism is an inadequate basis for the good life in the good society: such a conception of the public good is essential to democracy but, sadly and tragically, usually absent (and even cynically ridiculed) from the currently more vociferous and dominant ideology of individualism and free market economics. Periclean Athens, we should also recall, was the locus of a direct, participatory form of democracy, albeit on a very restricted franchise. Much the same, Brosio reminds us, is true of aspects of our religious tradition. Although he does not use the term, there have been varieties of Christian Socialism, as well as models of direct democracy in religious sects like Congregationalism.

The dismissal by Brosio of what he believes to be the futile quest for certainty does not lead him to opt for an alternative epistemological and moral relativism or, especially, the nihilism he finds in much of postmodern thought. As in his earlier text (A Radical Democratic Critique of Capitalist Education), he gives a clear and not entirely unsympathetic account of postmodernism (as accessible an account of this protean concept as any with which I am familiar).

Avoiding the extremes of philosophical certainty and of postmodern relativism, Brosio draws upon both Habermas and Deweyan pragmatism to find in the concepts of 'fallibilism' and 'warranted assertability' the grounding necessary to his philosophical and educational enterprises. Whilst warranted assertability is not truth, it is nevertheless superior to "everyone's opinion is as good as any other"; also providing the possibility that one can "live without certainty and yet not be paralysed by hesitation".

Richard Brosio's writing is intelligent, erudite and lucid, and this text will be invaluable to anyone who, like him, is concerned that a primary outcome of schooling must be citizens who take an active and critical stance to the political, economic and cultural dilemmas of our time.

\section{Notes}

1. New York, Peter Lang Publishing, Inc., 2000. 